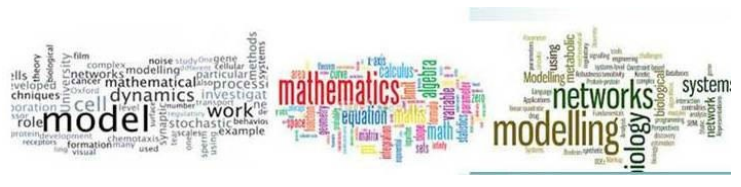

Journal, Advances in Mathematical \& computational Sciences

Vol. 10 No. 22022

www.mathematics-computationaljournal.info

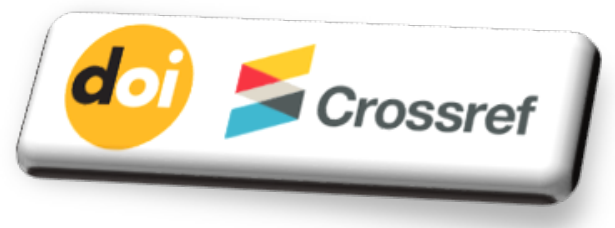

Journal of Advances in Mathematical \& Computational Sciences An International Pan-African Multidisciplinary Journal of the SMART Research Group International Centre for IT \& Development (ICITD) USA

(c) Creative Research Publishers

Available online at https://www.isteams.net/ mathematics-computationaljournal.info

DOI: dx.doi.org/10.22624/AIMS/MATHS/V10N2P2

CrossREF Member Listing - https://www.crossref.org/06members/50go-live.html

\title{
Impacts and Challenges of ICT on Service Delivery in Academic Libraries
}

\author{
Ihim, Christiana C. (CLN, AWLIN) \& Edom, Eunice Uchechi (PhD, CLN, AWLIN) \\ Professor Gabriel Umezurike Library \\ Imo State Polytechnic \\ Umuagwo, Imo State, Nigeria \\ E-mail: euniceedom@gmail.com
}

\begin{abstract}
This research focuses on the impact and challenges of ICT on the services delivery in academic libraries. Respondents were randomly selected among the librarians and library officers. The research adopted a survey research design to investigate a population of 119 staff drawn from the academic libraries. A structured questionnaire was used to collect data. Data gathered were presented in tables and analyzed using mean value and percentages. The results show that majority of the service delivery in the library such as Selective Dissemination of Information and Current Awareness Services, reference services delivery, User Education, circulation, Acquisition, research and development are carried out using ICT. The study also show that ICT has made service delivery in library faster and quicker, provides up to date information, provides remote access of information to users. The study also reveals poor attitude of staff to ICT, lack of ICT skill/competence, erratic power supply and lack of equipment maintenance as some of the factors militating against the use of ICT in academic libraries service delivery. The research concludes that the application of ICT in the service delivery of academic libraries is necessary because it makes service delivery easy and worthwhile and therefore should be encouraged. The study therefore recommends the installation of ICT facilities in the library and adequate ICT training of library staff for effective and efficient service delivery.
\end{abstract}

Keywords: Libraries, Academic, ICT, Services, Delivery, Impacts, Challenges

Ihim, C.C. \& Edom, E.U. (2022): Impacts and Challenges of ICT on Service Delivery in Academic Libraries

Journal of Advances in Mathematical \& Computational Science. Vol. 9, No. 2. Pp 13-20. DOI:

dx.doi.org/10.22624/AIMS/MATHS/V10N2P2

Available online at www.isteams.net/mathematics-computationaljournal. 


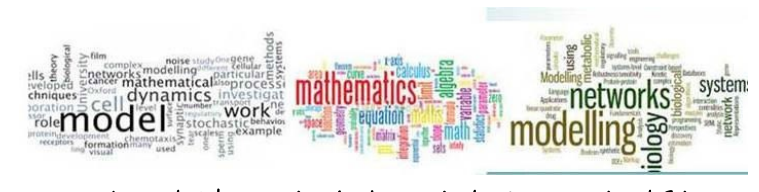

Journal, Advances in Mathematical \& computational Sciences

Vol. 10 №. 2,2022

www.mathematics-computationaljournal.info

\section{INTRODUCTION}

Academic libraries have essential roles to play within and outside their parent institutions. They have the role of providing information for research, teaching and learning to staff and students both within and outside their parent institution. They make the relevant information readily available and accessible to library users by acquiring, processing, organizing, storing, retrieving and disseminating information resources to library users. In this era of information explosion, this services will be hampered without ICT. Oyedun 2007 opines that ICT has in no small measure enhanced the services of the libraries in achieving these roles.

He defines academic libraries as those libraries that are mainly found in tertiary institutions, they are established to support learning, teaching and research process. American Library Association (ALA) define Information Technology as the application of computers and other related technologies to the acquisition, storage, retrieval and dissemination of information. In extension, Mathew (2012) sees ICT as the mechanism used to process, store and transmit information which could be in numeric or text. From the above definitions, one can deduce that ICT holds the key to effective and more appropriate library operations and services. ICT has impacted positively in different operations and services of the library such as Online Public Access Catalogue (OPAC), Current Awareness Service, Document Delivery, inter library loan.

In the bid to fully integrate ICT into the services of the library, library and information centers face a lot of challenges. Tiamiyu et al(2002) write that the use of computer brings with it fatigue, computer addiction and obsession, cumulative trauma disorders, stress and other occupational safety and health related problems as well as social problems like isolation, alienation depersonalization etc. Inadequate funding, lack of ICT policies, lack of equipment maintenances, lack of technical know how of staff have posed serious challenges to ICT application to library service delivery.

\subsection{Statement Of The Problem:}

In spite of the numerous impacts of ICT to libraries operations and services, many Academic libraries have not fully incorporated it in their operations and service delivery, the study was therefore undertaken to ascertain the problems associated with ICT in service delivery of the library.

\subsection{Significance Of The Study}

This study will help to acquaint both the library management, management of institutions and library employee with better understanding of what they stand to gain when they integrate ICT into their service delivery.

\subsection{Objective Of The Study}

The objectives of this research are as follows:

To identify the type of library services carried out using ICT in academic libraries

To ascertain the impact of ICT on library services.

To ascertain the challenges of ICT on effective service delivery in academic libraries.

To proffer solutions to identified challenges 


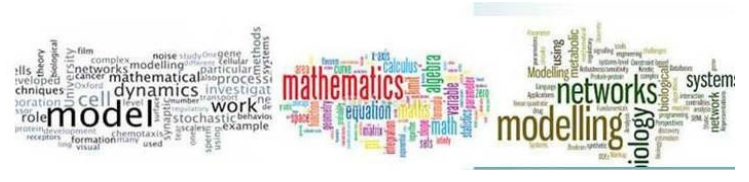

Journal, Advances in Mathematical \& computational Sciences

Vol. 10 No. 2,2022

www.mathematics-computationaljournal.info

\section{LITERATURE REVIEW}

The impact ICT has in the delivery of library services in academic libraries cannot be over emphasized. Omogor (2006) refers ICT as the system for producing, storing, sending and receiving digital files, it is a conveyance of interest between electronic computing and communication all leading to the rapid development of microelectronics.. In this era of information explosion, ICT becomes an answered call in the organization and control of knowledge. Uwaifo states that the potentials of ICT can be maximized as long as they serve the through purpose of college libraries, which among other things is to support and aid research. This therefore buttresses the importance of ICT in library service delivery. In the words of Krubu and Osawaru (2011).

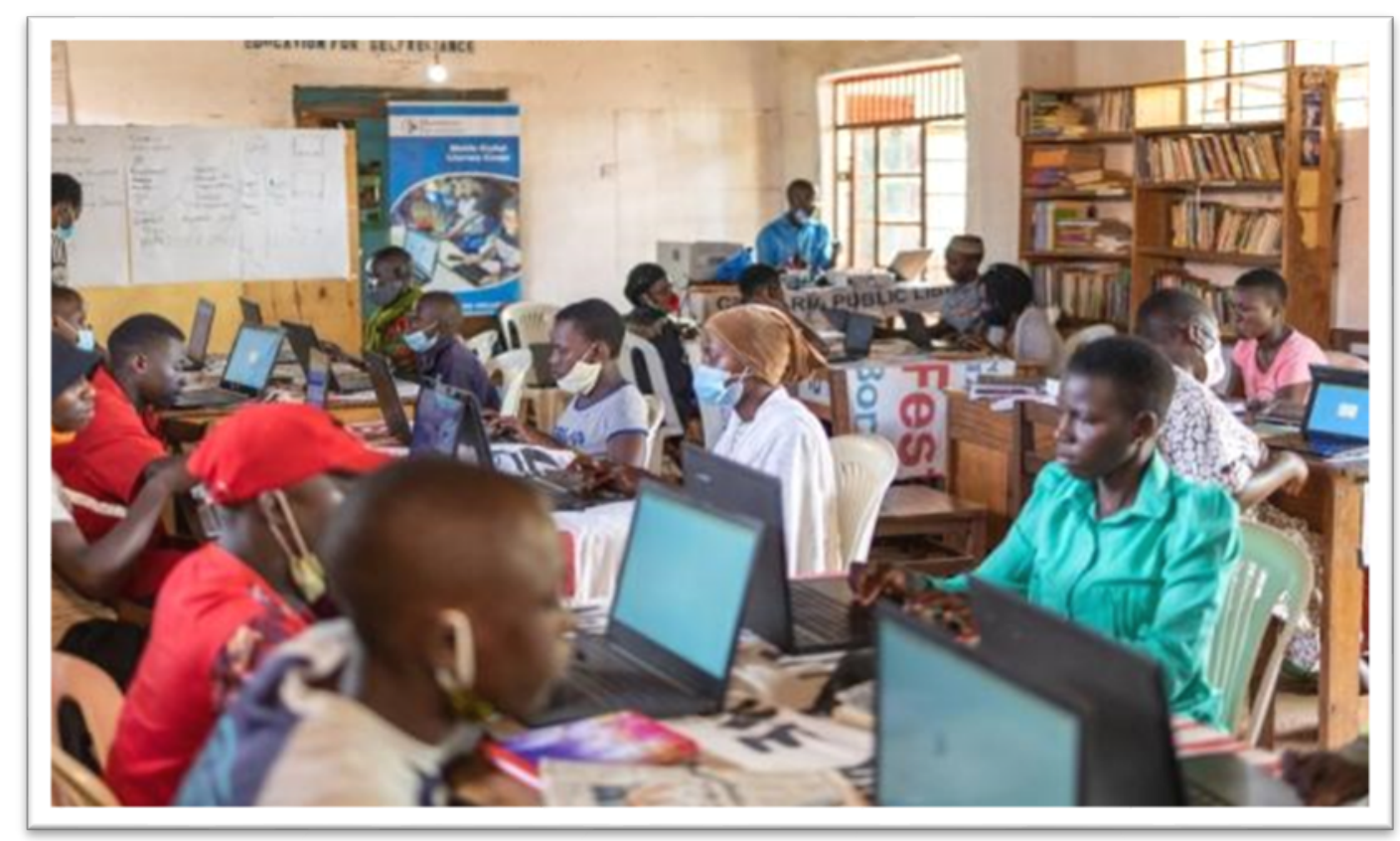

Fig. 1 : Use of ICTs in the Library

Source: https://www.eifl.net/news/

ICT has impacted on every sphere of academic library activities especially in the form of collection development strategies, library building and consortia, ICT presents an opportunity to provide valueadded information services and access to a wide variety of digital based information resources to their clients. Awuori etal (2013) observes that ICT has led to the development of new professional paradigm within the field of librarianship by meeting the students needs in fulfilling their course assignments and thereby enhancing programs, meeting teaching and research needs, accommodating other informational needs of the distance learning community as appropriate. This according to them run contrary to the traditional library services whereby the users have to be present in order to access the wide range of information services needed to satisfy their information needs. 


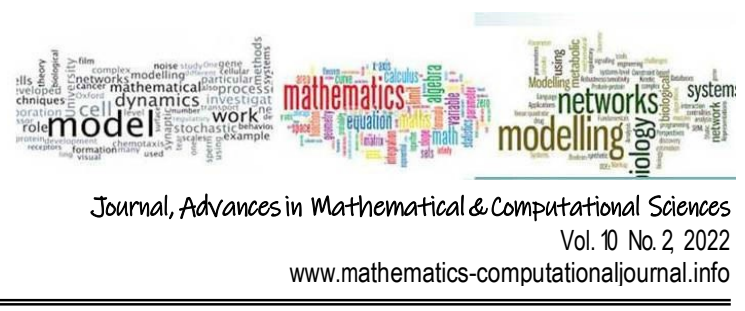

Ojo (1999) opines that Information communication technology is rapidly transforming the content and services of information centers worldwide. Libraries are gradually changing the manual/traditional ways of carrying out library activities and services to the use of ICT which has indeed enhance these activities. These changes according to Nwachukwu (2005) is manifested in the conversion of printed bibliographic sources into CD-ROM, Database, direct access to remote database online and the attendance shift in remote search strategies. On the other hand, some important library publications in printed form such as library journals, newsletters, books etc can now be found online.

ICT has increased the range of services offered in the library. Library staff can give immediate response to users reference queries of when, where, why, what, how, using ICT. It has increased efficiency, provides speedy and easy access to information, provides round the clock access of information to users, provides access to up-to-date and unlimited information from different sources. ChaudHary (2011)highlights some of the benefits of ICT to the library services, he states that: (a) With the increasing use of Email, internet access and online data base some libraries now make use of systems librarians who are responsible for the design of website, intranet, maintain electronic Email and data base systems.(b) the library records can be organized and stored online in a data base for easy accessibility (c) many corporate librarians are becoming information consultants both for the internal and external clients, with the help of the internet, this has to be done even from remote areas (d).with the aid of ICT, some libraries now catalogue their materials online.(e). Through the use of computer the visually impaired persons can use voice input device or a remote voice system to enter commands. He further explains that one of the leading areas in the library is making information accessible to every employee.

The training of employees to perform library services such as online catalogue, the internet, intranets and other online data bases are becoming common practice within the libraries. This activity is very much enhanced with the aid of ICT. Libraries offer training classes/instructions at every computer work station using projectors, power point presentation. Keller (2001) explains that Talking thermometer and talking compasses have been used to facilitate teaching among the visually impaired students. Chisenga acknowledges the role of ICT application which he said had improved the service delivery of libraries and allied institutions responsible for information provision.

Despite the enormous benefits which ICT portray a lot of factors still militate against its application in the service delivery of the library. Lack of skilled manpower to handle ICT facilities has been a major treat to ICT. Ekoja (2007) in support of this writes that, there is no doubt that many librarians in Nigerian universities are unable to use ICTs, even in libraries where they are available and that the situation if not reversed, poses a serious setback to Nigerian university librarians' effort to provide information to their clientele.. Machine obsolete is another issue to the use of ICT. In most libraries when the ICT equipment becomes moribund it is usually difficult to change or purchase new ones. Chaud Hary (2017) acknowledges that technological life span of any ICT equipment and its associated hardware and software is a major issue, computer hardware and software both change rapidly with new version of each coming out on regular basis, libraries will probably not be able to use many of the technologies of today in future, certainly, parts of the hardware will no longer be manufactured and old software will eventually not work on new machines. 


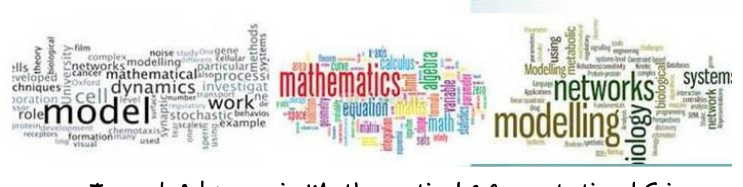

Journal, Advances in Mathematical \& computational Sciences

Vol. 10 No. 2, 2022

www.mathematics-computationaljournal.info

This is definitely a serious challenge because libraries may not be able to retrieve information stored on those equipment in the next 30 years and it will certainly be a big problem in the next 100 years. Lack of maintenance culture is very crucial to mention in the use of ICTs in libraries, because maintenance of these equipment are highly neglected, employees see them as government property therefore tend to mishandle them, once they become faulty they are totally abandoned

\section{DATA PRESENTATION AND ANALYSIS}

In this section we present research data and their analysis

TABLE 1: What The Types Of Library Services Performed Using let?.

\begin{tabular}{|l|l|l|l|l|l|l|}
\hline & LIB SERVICES USING ICT & SA & A & D & SD & MEAN(x) \\
\hline A & Interlibrary loan services & 31 & 56 & 19 & 13 & 2.88 \\
\hline B & SDI/CAS & 51 & 48 & 10 & 10 & 3.16 \\
\hline C & Reference Services & 50 & 48 & 11 & 10 & 3.16 \\
\hline & User Education & 83 & 30 & 6 & 0 & 3.65 \\
\hline E & Research and development & 43 & 31 & 19 & 13 & 2.88 \\
\hline F & Circulation & 50 & 37 & 19 & 13 & 2.88 \\
\hline G & OP AC & 31 & 56 & 19 & 13 & 2.88 \\
\hline H & Acquisition & 56 & 31 & 19 & 13 & 2.88 \\
\hline & Significant=2.77 & & & & & \\
\hline
\end{tabular}

As shown on the above table I with a significant mean value of 2.77 , all the library services can be carried out using ICT All the services listed were significant because their mean values are greater than the expected significant value of 2.77 .

These services were Selective Dissemination of Information(SDI) and Current Awareness Services(CAS) (x3.16), Reference Services(x3.16),User Education, Research and Development(x2.88]Online Public Access Catalogues (OPAC) and Interlibrary Loan Services (2.88).

Table II: What Are The Impacts Of let On Library Services?

\begin{tabular}{|l|l|l|l|l|l|l|}
\hline \hline & IMPACT OF ICT TO LIB SERVICES & SA & A & D & SD & MEAN(x) \\
\hline A & Makes service deliver quicker and faster & 51 & 36 & 20 & 12 & 3.06 \\
\hline B & Expands extent of services available to users & 48 & 47 & 15 & 09 & 2.87 \\
\hline C & Provides up to date information services & 42 & 55 & 10 & 13 & 2.93 \\
\hline D & $\begin{array}{l}\text { Provides remote access of information } \\
\text { sources to users }\end{array}$ & 47 & 48 & 15 & 09 & 2.87 \\
\hline E & Makes academic libraries relevant & 55 & 42 & 10 & 13 & 2.93 \\
\hline & Significant mean value=2.80 & & & & & \\
\hline
\end{tabular}




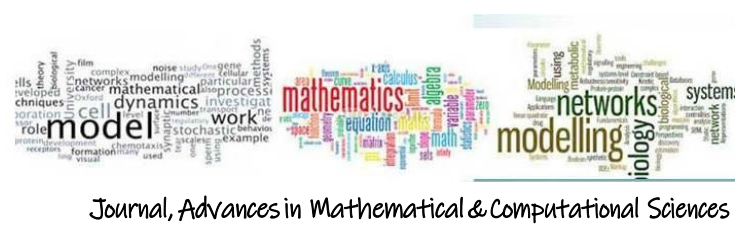

Vol. 10 No. 22022

www.mathematics-computationaljournal.info

A number of factors show that ICT has great impact in academic libraries services delivery at significant mean value of 2.80 as shown in Tablell. The responses show that ICT makes service delivery faster (x3.06), makes academic libraries relevant (2.93), provides up to date information services, (x2.93) and provides remote access of information sources to users (x2.87),also provides extent of services available to users (x2.87). This shows that there is no limit to what ICT can be used to perform.

Table 111: What Are The Challenges Of let To Effective Service Delivery In Libraries?

\begin{tabular}{|l|l|l|l|l|l|l|}
\hline & Militating factors & SA & A & D & SD & MEAN $(X)$ \\
\hline A & Poor attitude of library staff to ICT & 51 & 36 & 20 & 12 & 3.06 \\
\hline B & Lack of ICT skill/competence of library staff & 53 & 30 & 19 & 17 & 2.81 \\
\hline C & Erratic power supply & 26 & 13 & 42 & 39 & 2.93 \\
\hline D & Frequent change in technology & 51 & 26 & 15 & 27 & 2.34 \\
\hline E & Lack of equipment maintenance & 48 & 32 & 30 & 0.9 & 2.87 \\
\hline F & Machine obsolete & 51 & 36 & 20 & 12 & 3.06 \\
\hline & Significant at 2.80 & & & & & \\
\hline
\end{tabular}

A number of factors militate against the use of ICT in the delivery of library services. At a significant mean value of x.2.80 as shown on table iii above. The factors include poor attitude of staff to ICT (x 3.06) and machine obsolete (x3.06) which has the highest mean value. Lack of ICT skill/competence (x2.81), Erratic power supply (x2.93). Lack of equipment maintenance (x2.87). However frequent change in technology (x2.34) did not pose any significant obstacle, the mean value is less than the significant mean value of (x2.80), This is may be because it is not a common practice for libraries to change their equipment often.

TABLE IV: What Are The Solutions To Identified Challenge Of ICT To Library Service Delivery?

\begin{tabular}{|l|l|l|l|}
\hline & SOLUTIONS & RESPONSES & $\%$ \\
\hline A & Staff should developed Positive attitude towards ICT & 79 & 94.1 \\
\hline B & Adequate training should be giving to staff & 74 & 88.6 \\
\hline C & Power should be supplied regularly to libraries & 68 & 80.92 \\
\hline D & Equipment maintenance culture should be improved. & 64 & 76.19 \\
\hline E & $\begin{array}{l}\text { Alternative means of saving information from ICT should be } \\
\text { sought. }\end{array}$ & 79 & 94.1 \\
\hline
\end{tabular}

From table iv above, respondents suggested a number of measures to be taken in order to ameliorate the challenges posed by ICT in carrying out library services. Majority of the respondents suggested that Academic libraries should sought for alternative way of saving their information in case of any eventuality and that library staff should develop positive attitude towards ICT 79 ( $94.1 \%$ ) some of the respondents suggested that adequate training should be given to library staff, 74 $(88.6 \%)$, this may be because they understand that well trained library personnel is a major resource to the library. others suggested provision of regular power supply $68(80.92 \%)$ and the maintenance of existing ICT equipment. 64 (76.16\%). 


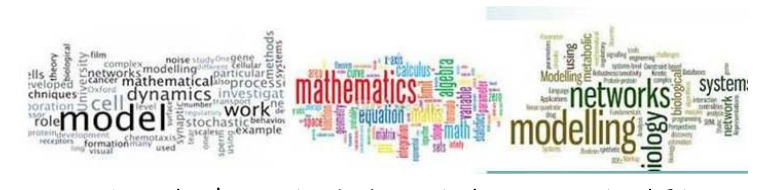

Journal, Advances in Mathematical \& computational Sciences

Vol. 10 No. 2,2022

www.mathematics-computationaljournal.info

\section{CONCLUSION}

In conclusion the use of ICTs in academic libraries service delivery is a right step in the right direction. ICT has greatly impacted the services of the libraries and has made library and librarians remain relevant in this era of information explosion. It has speed up the activities of information handling in the library thereby projecting the world as a global village.

\section{RECOMMENDATIONS}

The paper recommends the establishment of ICT facilities in the libraries. Provision and implementation of ICT Policies to libraries for efficient and effective service delivery. The paper also recommends adequate ICT training for the staff of the library.

\section{REFERENCES}

1. Amechi, N.M, Enweani, U.V., and Eke, C.C. (2015). Challenges of library and information service (LIS) delivery in the 2ist Century: the situation in three academic libraries in Imo State Nigeria. Library Philosophy and Practice.

2. Awuori, F.M. Rabah, K. and Maake, B.M.(2013). Hindrance of ICT adoption to library services in higher institution of learning in developing countries. Computer Science Information Technology 1(4) PP 252.

3. Chaudhary, S. K.(2011) Encyclopaedia of Teaching of Library Science: Library preservation and conversation. New Delhi: A. P. H. Publishing Corporation Vol. 5

4. Chaudhary, S. K.(2011) Encyclopaedia of Teaching of Library Science: library marketing. New Delhi: A. P. H. Publishing Corporation Vol. iii.

5. Chisenga, J.(1995) The skills of information technology in Zambian libraries. in Ekoja, Innocent (2007). information and communication technology (ICT): librarians knowledge, use and skill in Nigerian university libraries. Communicate 9(1)

6. Keller, (2001) Strategies for teaching students with vision impairment. in Akinbode, F.A, Amusa, R. O. and Odunewu, A.O.(2009) Current trends in library and information science. Library Philosophy and Practice. Pp 289-298.

7. Krubu D. E. and Osawara K. E. (2011).The impact of information and communication technology (ICT) in Nigerian university libraries. Library philosophy and practice. E journal. Retrieved from http///uni.lib. philosophy and practice, on July, 2019.

8. Mathew S.K.(2012) Developing technologies skills for academic librarians: a study based on the university of Kerela, India. Library Philosophy and Practice (e journal) accessed from www.dgitalcommons,edu.>

9. Nwachukwu, V.N. (2005) Information technology application to libraries in developing countries. The need for coalition. Global Review of Library and Information Science. 1(1)2005.

10. OJO igbinoba, M.F (1999). The potential of CD-ROM technology in African libraries. African journal of libraries, Archiives and information science 3(2) 157-167.

11. Omorgor, I.M. (2006) Assessment of the use of information technology in Nigerian universities: a case study of Delta State University, Abraka. Nigerian Library Link $\quad$ (4) $1 \& 2$, 79-86 


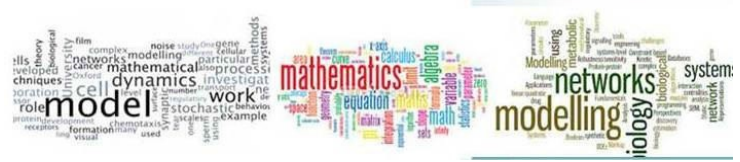

Journal, Advances in Mathematical \& computational Sciences

Vol. 10 No. 22022

www.mathematics-computationaljournal.info

12. Oyedun, (2007) in Amechi, N.M, Enweani, U.V., and Eke, C.C. (2015). Challenges of library and information service (LIS) delivery in the 2ist Century: the situation in three academic libraries in Imo State Nigeria. Library Philosophy and Practice

13. Technology Boost For Public Libraries In Uganda. https://www.eifl.net/news/

14. Tiamiyu (2002) in Anumobi, C.V. (2005) ICT availability and use in Nigerian university libraries. Global Review of Library Information Science, 1(1) pp. 40.

15. Uwaifo, S.O.(2010) Information communication technology and library service in society. Modern library and information science for information professionals in Africa pp237-238 